\title{
The Influence of Knowledge Sharing, Affective Commitment, and Meaningful Work on Employee's Performance
}

\author{
Submitted 04/05/20, $1^{\text {st }}$ revision 05/06/20, $2^{\text {nd }}$ revision 02/07/20, accepted 20/07/20
}

Ahyar Yuniawan ${ }^{1}$, Udin Udin $^{2}$

\begin{abstract}
:
Purpose: The research aimed to test the influence of knowledge sharing, affective commitment, and meaningful work on the performance of the employee. This study was conducted in Indonesia, specifically in the banking sector.

Design/Methodology/Approach: Data collection of this study used administered questionnaires among employees. Thus, 219 questionnaires were returned and analyzed using SmartPLS 3 software.

Findings: The study revealed that knowledge sharing and meaningful work significantly affect the performance of the employee. In contrast, affective commitment did not influence the performance of the employee. This study further showed that meaningful work mediated the correlation between knowledge sharing and the performance of employees.

Practical implications: This study's findings contribute to the literature review advancement related to the associations among knowledge sharing, affective commitment, meaningful work, and the performance of employees.

Originality/value: This paper is the first empirical study to uncover the impact of knowledge sharing, affective commitment, and meaningful work on the performance of employees in the Indonesian banking sector.
\end{abstract}

Keywords: Knowledge sharing, affective commitment, meaningful work, employee's performance.

JEL codes: D21, D22, D83.

Paper type: Research article.

\footnotetext{
${ }^{1}$ Business and Economic Faculty, Universitas Diponegoro, Semarang, Indonesia

${ }^{2}$ Business and Economic Faculty, Universitas Muhammadiyah Yogyakarta, Yogyakarta, Indonesia, E-mail: udin_labuan@yahoo.com
} 


\section{Introduction}

Well-perform employees can be the most crucial assets in the corporation, and knowledge sharing carries out an important task in influencing employee's performance and organizational success (Swanson, Kim, Lee, Yang, and Lee, 2020). It is no exception for organizations engaged in the service sector, which are faced with increasing market competition.

Knowledge is regarded as the most vital asset and resource for the organization. Knowledge sharing among employees becomes very important to achieve organizational efficiency and effectiveness. In the setting of organization, knowledge is shaped and maintained once employees initiate and communicate their knowledge toward others. Wang and Ahmed (2003) emphasized several contexts that are principle, where organizational knowledge is formed and communicated.

Knowledge sharing has been widely recognized as a very important social asset for the organization, which can improve the performance and drive the success of an organization (Masa'deh, Obeidat, and Tarhini, 2016; Razmerita, Kirchner, and Nielsen, 2016). Concurrently, the service in the banking sector is produced and consumed, resulting in relatively much space make various mistakes. Therefore, knowledge management, especially knowledge sharing, becomes very important to prevent failures and errors in service delivery. Therefore, this study seeks to test whether knowledge sharing positively affects employee performance, which is mediated by affective commitment and meaningful work.

\section{Literature Review}

\subsection{The Performance of Employee}

Performance is a collection of people's activities or acts in line with the objectives of the organization. Gavin, Frederiksen, Robbins, Pazol, and Moskosky (2017) consider performance as an aggregation of the outcomes of all organizational work activities and processes. As affirmed by Mathis and Jackson (2009), performance is associated with job quality, job quantity, job attendance, timeliness, job effectiveness, and job efficiency. It is extremely necessary for all companies to maintain a high standard of performance, as the performance of employees is linked to the sustained development of the organization directly (Burney, Henle, and Widener, 2009). Triggered by globalization, each corporation experiences an incredible burden to increase the general performance. In this condition, workers are required to build their resources of psychological and physical by stressing emotional bonds of high affective commitment, values' suitability, and culture in the corporation that is assumed to generate greater performance (Curcuruto and Griffin, 2018; Hirunyawipada and Xiong, 2018; Latan, Jabbour, de Sousa Jabbour, Wamba, and Shahbaz, 2018). 


\subsection{Affective Commitment}

Affective commitment explains the intimate and relational interaction bond of organization and employees. As stated by Bingham, Mitchell, Bishop, and Allen (2013), the emotional connection of the workers toward the association is signified as affective commitment. Glazer and Kruse (2008) consider affective commitment as an employee's desire to stay as part of the organization, work together for the corporation, and trust the organization's values and norms. Workers with affective commitment consistently desire to continue working in the association and love to be the association's member since they trust the association's values and norms ( $\mathrm{Ng}$ and Allen, 2018).

Employees who own affective commitment recognize themselves in the association, take part in the activities of the association, and seek after the objectives of the association (Bingham et al., 2013). Affective commitment is one main booster that causes workers to partake in increasing the association's performance. When workers are committed to the association concerning affective aspects, they will emotionally be inspired to exhibit their performance. Under academic examinations, researchers have given significant consideration to the connection between the commitment of the organization and the performance of the employee (Jaramillo, Mulki, and Marshall, 2005; Riketta, 2002). A positive attitude toward job and better performance were displayed by workers who have a high commitment toward organization compared to workers who are not committed (Harrison, Newman, and Roth, 2006; Meyer, Stanley, Herscovitch, and Topolnytsky, 2002).

\subsection{Meaningful Work}

Meaningful work alludes to job experience specifically and owns a progressively positive significance for a person (Rosso, Dekas, and Wrzesniewski, 2010). Lysova, Allan, Dik, Duffy, and Steger (2018) define meaningful work as work that has significant personal value and is useful. Meaningful work is eudemonic (goaloriented and growth-oriented), not hedonistic (pleasure-oriented). Lips-Wiersma and Morris (2009) identified four meaningful sources of work, namely a) being oneself and developing one's potential; b) unite with others; c) help others; and d) express themselves. Meaningful work experience creates a tension between the need to fulfill oneself (needs of the self/needs of being) and the need to fulfill others (needs for others/needs for doing) (Lips-Wiersma and Wright, 2012).

\subsection{Knowledge Sharing}

Knowledge sharing is defined as giving knowledge and information to assist and cooperate with others to resolve issues, grow new thoughts, or apply work procedures and policies (Cummings, 2004). It also refers to social interaction culture involving the interchange of workers' experience, skills, and knowledge in a whole office or association (Lin, 2007). Sharing of knowledge happens when somebody is 
eager to learn (e.g., gather information) and assist (i.e., contribute information) others in growing new capacities. It is a procedure where people exchange information and jointly generate new information. It signifies that knowledge sharing is a communication process between at least two people that involves "acquisition" (e.g., knowledge gathering) and "provision" (e.g., knowledge contribution) (Usoro, Sharratt, Tsui, and Shekhar, 2007).

\section{Hypotheses Development}

\subsection{The Influence of Knowledge Sharing, Affective Commitment, and Meaningful Work on the Performance of Employee}

One of the ways to achieve a successful corporation is by constructing an environment-based knowledge sharing, where workers communicate the knowledge they have acquired and enable others to access their intellectual resources that are useful to improving their work. Previous studies (Masa'deh et al., 2016; Sulistiyani, Udin, and Rahardja, 2018; Swanson et al., 2020; Wahyudi, Udin, Yuniawan, and Rahardja, 2019) support training for employee - a formal kind of knowledge-sharing at the level of organization - which is very important to improve employee's performance and organizational performance. As the time knowledge is shared, workers will be able to access intellectual resources and acquire essential skills for increasing and improving their work. Therefore, the research hypotheses can be stated as follows:

H1: Knowledge sharing significantly affect employee' performance;

H2: Knowledge sharing significantly affect affective commitment;

H3: Knowledge sharing significantly affect meaningful work.

\subsection{The Influence of Affective Commitment on the Performance of Employee}

Meyer et al. (2002) deem substantial affective commitment able to enhance behavior conduct that is useful to achieve the objectives determined by the association. Workers own high enthusiasm levels to work and accomplish the objectives determined by association because they have a high affective commitment, resulting in the sense of belonging toward the association. Chang and Chen (2011) affirm that affective commitment has a reliable correlation to the performance of the employee. Employees who are committed have a more noteworthy inclination to work together reliably than what the association anticipates. This research result is likewise upheld by numerous examinations (Kim, 2014; Semedo, Coelho, and Ribeiro, 2016; Sharma and Dhar, 2016; Swalhi, Zgoulli, and Hofaidhllaoui, 2017; Udin, Handayani, Yuniawan, and Rahardja, 2017) that affective commitment affects employee' performance. Therefore:

H4: Affective commitment significantly affect the performance of the employee. 


\subsection{The Influence of Meaningful Work on the Performance of Employee}

In the context of organizational life, work feels meaningful when: (a) is seen as a useful pursuit for broader purposes; (b) provide opportunities for self-realization and self-actualization (Martela and Pessi, 2018). Meaningful work has been seen as a protective resource, to make unwanted conditions better (Lips-Wiersma and Wright, 2012), and as an important mediator variable that links job characteristics with work outcomes (Humphrey, Nahrgang, and Morgeson, 2007; Simonet and Castille, 2020). Therefore:

H5: Meaningful work significantly affect the performance of the employee.

\section{Research Methods}

\subsection{Research Samples and Data Collection}

A sample is a part of the population defined to generalize research results, while a population is a group of people who have shared and related qualities (Dornbos and LaPres, 2017). This study population was all employees who worked at Bank Rakyat Indonesia (BRI) in Central Java. This study sample employed a simple random sampling technique, determining 300 employees. From the results of the distribution of questionnaires, 219 questionnaires were declared eligible to be processed and analyzed. The majority of respondents in this study were women (57\%) with undergraduate education (S1).

\subsection{Measurement}

The questionnaire was spread to respondents, consisting of 17 question items. All question items were measured using a 5-points Likert scale, where one means strongly disagree, and five signifies strongly agree. Knowledge sharing was calculated by four indicators adapted from Kim and Lee (2013). The affective commitment was determined by employing four items that were adopted from Vandenberghe, Bentein, and Stinglhamber (2004). Meaningful work measurement involved five questions that were adapted from Steger, Dik, and Duffy (2012). Moreover, the performance of employees was gauged, utilizing four indicators that were adopted from the In-role Performance Scale (Ghosh, Sekiguchi, and Gurunathan, 2017).

\subsection{Data Analysis Technique}

In this study, after data being collected, they were processed and then analyzed utilizing Structural Equation Modeling (SEM) with SmartPLS 3.0 software. PLSSEM is one of the most useful analytical tools for elaborating theories in the study of management. PLS-SEM has a significant flexibility level for relations between data and theory, which particularly associated with the increasingly comprehensive 
improvement of cause and effect pathways (Nitzl, 2016). Identification and other technical aspects do not constrain PLS-SEM, so it is conceivable to examine complex models with different indicators and constructs (Rigdon, 2014).

\section{Results and Discussion}

The data analysis findings in this study through the SmartPLS 3.0 software are detailed in Tables 1-3 below.

Table 1. Cross Loadings among Variables

\begin{tabular}{|c|c|c|c|c|}
\hline & $\begin{array}{c}\text { Affective } \\
\text { Commitment }\end{array}$ & $\begin{array}{c}\text { Employee } \\
\text { Performance }\end{array}$ & $\begin{array}{c}\text { Knowledge } \\
\text { Sharing }\end{array}$ & $\begin{array}{c}\text { Meaningful } \\
\text { Work }\end{array}$ \\
\hline AC1 & 0.778 & & & \\
\hline AC2 & 0.558 & & & \\
\hline AC3 & 0.802 & & & \\
\hline AC4 & 0.809 & & & \\
\hline EP1 & & 0.566 & & \\
\hline EP2 & & 0.849 & & \\
\hline EP3 & & 0.692 & & \\
\hline EP4 & & 0.839 & 0.553 & \\
\hline KS1 & & & 0.756 & \\
\hline KS2 & & & 0.796 & \\
\hline KS3 & & & & 0.637 \\
\hline KS4 & & & & 0.712 \\
\hline MW1 & & & & \\
\hline MW2 & & & & 0.759 \\
\hline MW3 & & & & \\
\hline MW4 & & & & \\
\hline MW5 & & & & \\
\hline
\end{tabular}

Source: Own.

Table 1 shows that the loading factor of all indicators for each variable is good, which is above 0.5 . It indicates that these indicators are very feasible to be used in this study.

Table 2. Validity and Reliability Test

\begin{tabular}{|l|c|c|c|}
\hline \multicolumn{1}{|c|}{ Construct } & AVE & Composite Reliability & Cronbach' Alpha \\
\hline Affective Commitment & 0.554 & 0.829 & 0.724 \\
\hline Employee Performance & 0.556 & 0.830 & 0.724 \\
\hline Knowledge Sharing & 0.514 & 0.806 & 0.691 \\
\hline Meaningful Work & 0.509 & 0.838 & 0.762 \\
\hline
\end{tabular}

Source: Own.

Table 2 confirms that each variable has a value of AVE $>0.5$, which means this study data have good validity. Likewise, the values of composite reliability and 
Cronbach alpha $>0.6$, which indicates high reliability. With this in mind, this research is very feasible to proceed with hypothesis testing.

Table 3. Path Coefficients

\begin{tabular}{|l|c|c|c|c|}
\hline \multicolumn{1}{|c|}{ Hypotheses } & $\begin{array}{c}\text { Original } \\
\text { Sample }\end{array}$ & $\begin{array}{c}\text { Sample } \\
\text { Mean }\end{array}$ & $\begin{array}{c}\text { Standard } \\
\text { Deviation }\end{array}$ & $\boldsymbol{\beta}$ \\
\hline $\begin{array}{l}\text { Knowledge Sharing } \rightarrow \text { Employee } \\
\text { Performance }\end{array}$ & 0.299 & 0.303 & 0.135 & 2.219 \\
\hline $\begin{array}{l}\text { Knowledge Sharing } \rightarrow \text { Affective } \\
\text { Commitment }\end{array}$ & 0.735 & 0.748 & 0.029 & 25.311 \\
\hline $\begin{array}{l}\text { Knowledge Sharing } \rightarrow \text { Meaningful } \\
\text { Work }\end{array}$ & 0.648 & 0.663 & 0.043 & 15.134 \\
\hline $\begin{array}{l}\text { Affective Commitment } \rightarrow \text { Employee } \\
\text { Performance }\end{array}$ & 0.140 & 0.141 & 0.174 & 0.808 \\
\hline $\begin{array}{l}\text { Meaningful Work } \rightarrow \text { Employee } \\
\text { Performance }\end{array}$ & 0.356 & 0.356 & 0.195 & 1.827 \\
\hline
\end{tabular}

Source: Own.

From Table 3, the hypothesis testing results show that of the 5 hypotheses proposed in this study, $\mathrm{H} 4(\beta=0.808)$ is rejected, while $\mathrm{H} 1(\beta=2.219), \mathrm{H} 2(\beta=25.311), \mathrm{H} 3$ $(\beta=15.134)$, and H5 $(\beta=1.827)$ are accepted. Based on the r-square value, knowledge sharing affects affective commitment by $53.9 \%$, meaningful work by $42.1 \%$, employee performance by $52.6 \%$, and the rest are influenced by other factors that have not been explored in this study.

The results of this study confirm that affective commitment is developed on the grounds that a person's values correspond to the organization's interest. Affective commitment happens when people recognize the association's values and goals, in which people feel that they are parts and members of the association and that the association thinks about their conditions (Casimir, Ng, Wang, and Ooi, 2014). People who are emotionally committed to the association will be glad to proceed with their participation in the association and respect each issue in the association as their concern also. Thus, they will be completely engaged with the association and glad to work for the association (Ugboro, 2006).

Knowledge sharing encourages workers to regularly communicate with coworkers with full involvement in creative work behavior. When employees share knowledge, their access is more open to relevant knowledge possessed by coworkers so that it can spur cognitive abilities to overcome various difficulties at work (Wang and Noe, 2010). Sharing knowledge can also help employees in controlling and managing work difficulties because they can consult with others and learn more about how to overcome challenges when they start working (Cabrera and Cabrera, 2005). Likewise, the support experienced by employees through open communication can produce positive energy that can encourage higher work creativity. 
Employees always hope that their work is more meaningful and not just a source of income (Dik, Duffy, and Eldridge, 2009). Employees gain meaning from work when they have the opportunity to really involve themselves in significant job activities (Steger, Littman-Ovadia, Miller, Menger, and Rothmann, 2013). When work has a more important place in the lives of employees, they tend to invest themselves totally in work. In fact, meaningful work can be considered as a motivating force that drives organizational commitment and employee involvement in their work. Likewise, Steger, Dik, and Duffy (2012) assert that workers who experience meaning in work, they could show a higher commitment to the work and organization.

\section{Conclusion}

This research concludes that knowledge sharing and meaningful work significantly affect the performance of the employee. In contrast, affective commitment had no effect on the performance of the employee. Further, this study uncovered that meaningful work mediated the correlation between knowledge sharing and the performance of employees. This study results contribute to the literature review advancement related to the correlations among knowledge sharing, affective commitment, meaningful work, and employee performance.

\section{References:}

Bingham, J.B., Mitchell, B.W., Bishop, D.G., Allen, N.J. 2013. Working for a higher purpose: A theoretical framework for commitment to organization-sponsored causes. Human Resource Management Review, 23(2), 174-189.

Burney, L.L., Henle, C.A., Widener, S.K. 2009. A path model examining the relations among strategic performance measurement system characteristics, organizational justice, and extra- and in-role performance. Accounting, Organizations and Society, 34(4), 305-321.

Cabrera, E.F., Cabrera, A. 2005. Fostering knowledge sharing through people management practices. International Journal of Human Resource Management, 16, 720-735.

Casimir, G., Ng, Y.N.K., Wang, K.Y., Ooi, G. 2014. The relationships amongst leadermember exchange, perceived organizational support, affective commitment, and inrole performance: A social-exchange perspective. Leadership \& Organization Development Journal, 35(5), 366-385.

Cummings, J.N. 2004. Work groups, structural diversity, and knowledge sharing in a global organization. Management science, 50(3), 352-364.

Curcuruto, M., Griffin, M.A. 2018. Prosocial and proactive "safety citizenship behaviour" (SCB): The mediating role of affective commitment and psychological ownership. Safety science, 104, 29-38.

Dik, B.J., Duffy, R.D., Eldridge, B.M. 2009. Calling and vocation in career counseling: Recommendations for promoting meaningful work. Professional Psychology: Research and Practice, 40(6), 625.

Dornbos, P., LaPres, J.J. 2017. Incorporating Population-Level Genetic Variability within Laboratory Models in Toxicology: From the Individual to the Population. Toxicology. 
Gavin, L., Frederiksen, B., Robbins, C., Pazol, K., Moskosky, S. 2017. New clinical performance measures for contraceptive care: their importance to healthcare quality. Contraception, 96(3), 149-157.

Ghosh, D., Sekiguchi, T., Gurunathan, L. 2017. Organizational embeddedness as a mediator between justice and in-role performance. Journal of Business Research, 75, 130137.

Harrison, D.A., Newman, D.A., Roth, P.L. 2006. How Important Are Job Attitudes? MetaAnalytic Comparisons of Integrative Behavioral Outcomes and Time Sequences. The Academy of Management Journal, 49(2), 305-325.

Hirunyawipada, T., Xiong, G. 2018. Corporate environmental commitment and financial performance: Moderating effects of marketing and operations capabilities. Journal of Business Research, 86, 22-31.

Humphrey, S.E., Nahrgang, J.D., Morgeson, F.P. 2007. Integrating motivational, social, and contextual work design features: a meta-analytic summary and theoretical extension of the work design literature. Journal of applied psychology, 92(5), 1332.

Jaramillo, F., Mulki, J.P., Marshall, G.W. 2005. A meta-analysis of the relationship between organizational commitment and salesperson job performance: 25 years of research. Journal of Business Research, 58(6), 705-714.

Kim, H.K. 2014. Work-Life Balance and Employees' Performance: The Mediating Role of Affective Commitment. Global Business and Management Research: An International Journal, 6(1), 37-51.

Kim, T.T., Lee, G. 2013. Hospitality employee knowledge-sharing behaviors in the relationship between goal orientations and service innovative behavior. International journal of hospitality management, 34, 324-337.

Latan, H., Jabbour, C.J.C., de Sousa Jabbour, A.B.L., Wamba, S.F., Shahbaz, M. 2018. Effects of environmental strategy, environmental uncertainty and top management's commitment on corporate environmental performance: The role of environmental management accounting. Journal of Cleaner Production, 180, 297-306.

Lin, H.F. 2007. Knowledge sharing and firm innovation capability: an empirical study. International Journal of Manpower, 28(3/4), 315-332.

Lips-Wiersma, M., Morris, L. 2009. Discriminating between 'meaningful work'and the 'management of meaning'. Journal of Business Ethics, 88(3), 491-511.

Lips-Wiersma, M., Wright, S. 2012. Measuring the meaning of meaningful work: Development and validation of the Comprehensive Meaningful Work Scale (CMWS). Group \& Organization Management, 37(5), 655-685.

Lysova, E.I., Allan, B.A., Dik, B.J., Duffy, R.D., Steger, M.F. 2018. Fostering meaningful work in organizations: A multi-level review and integration. Journal of Vocational Behavior. https://doi.org/10.1016/j.jvb.2018.1007.1004.

Martela, F., Pessi, A.B. 2018. Significant work is about self-realization and broader purpose: defining the key dimensions of meaningful work. Frontiers in psychology, 9, 363.

Masa'deh, R.E., Obeidat, B.Y., Tarhini, A. 2016. A Jordanian empirical study of the associations among transformational leadership, transactional leadership, knowledge sharing, job performance, and firm performance. Journal of Management Development, 35(5), 681-705.

Mathis, R.L., Jackson, J.H. 2009. Human Resource Management. Mason, OH, USA, SouthWestern Cengage Learning.

Meyer, J.P., Stanley, D.J., Herscovitch, L., Topolnytsky, L. 2002. Affective, Continuance, and Normative Commitment to the Organization: A Meta-analysis of Antecedents, Correlates, and Consequences. Journal of Vocational Behavior, 61(1), 20-52. 
Ng, T.W., Allen, T.D. 2018. Organizational attachment and health. Journal of Vocational Behavior.

Nitzl, C. 2016. The use of partial least squares structural equation modelling (PLS-SEM) in management accounting research: Directions for future theory development. Journal of Accounting Literature, 37, 19-35.

Razmerita, L., Kirchner, K., Nielsen, P. 2016. What factors influence knowledge sharing in organizations? A social dilemma perspective of social media communication. Journal of knowledge Management, 20(6), 1225-1246.

Rigdon, E.E. 2014. Rethinking Partial Least Squares Path Modeling: Breaking Chains and Forging Ahead. Long Range Planning, 47(3), 161-167.

Riketta, M. 2002. Attitudinal organizational commitment and job performance: a metaanalysis. Journal of organizational behavior, 23(3), 257-266.

Radomska, J., Wołczek, P. 2020. Integrative Perspective on Ambidexterity, Creativity and Networking: Literature Overview. European Research Studies Journal, 23(3), 3149. DOI: $10.35808 / \mathrm{ersj} / 1623$.

Rosso, B.D., Dekas, K.H., Wrzesniewski, A. 2010. On the meaning of work: A theoretical integration and review. Research in organizational behavior, 30, 91-127.

Semedo, A.S.D., Coelho, A.F.M., Ribeiro, N.M.P. 2016. Effects of authentic leadership, affective commitment and job resourcefulness on employees' creativity and individual performance. Leadership \& Organization Development Journal, 37(8), 1038-1055.

Sharma, J., Dhar, R.L. 2016. Factors influencing job performance of nursing staff: Mediating role of affective commitment. Personnel Review, 45(1), 161-182.

Simonet, D.V., Castille, C.M. 2020. The search for meaningful work: A network analysis of personality and the job characteristics model. Personality and Individual Differences, 152, 109569.

Stańczyk, E., Stańczyk, P., Szalonka, K. 2020. The Impact of Personality and Competence of Leaders on Business Success. European Research Studies Journal, 23(2), 612-623. DOI: $10.35808 / \mathrm{ersj} / 1612$.

Steger, M.F., Dik, B.J., Duffy, R.D. 2012. Measuring meaningful work: The work and meaning inventory (WAMI). Journal of Career Assessment, 20(3), 322-337.

Steger, M.F., Dik, B.J., Duffy, R.D. 2012. Measuring meaningful work: The work and meaning inventory (WAMI). Journal of Career Assessment, 20, 322-337.

Steger, M.F., Littman-Ovadia, H., Miller, M., Menger, L., Rothmann, S. 2013. Engaging in work even when it is meaningless: Positive affective disposition and meaningful work interact in relation to work engagement. Journal of Career Assessment, 21, 348-361.

Sulistiyani, E., Udin, U., Rahardja, E. 2018. Examining the effect of transformational leadership, extrinsic reward, and knowledge sharing on creative performance of Indonesian SMEs. Quality - Access to Success, 19(167), 63-67.

Swalhi, A., Zgoulli, S., Hofaidhllaoui, M. 2017. The influence of organizational justice on job performance: The mediating effect of affective commitment. Journal of Management Development, 36(4), 542-559.

Swanson, E., Kim, S., Lee, S.M., Yang, J.J., Lee, Y.K. 2020. The effect of leader competencies on knowledge sharing and job performance: Social capital theory. Journal of Hospitality and Tourism Management, 42, 88-96.

Udin, U., Handayani, S., Yuniawan, A., Rahardja, E. 2017. Antecedents and Consequences of Affective Commitment among Indonesian Engineers Working in Automobile 
Sector: An Investigation of Affecting Variables for Improvement in Engineers Role. International Journal of Civil Engineering and Technology, 8(10), 70-79.

Usoro, A., Sharratt, M.W., Tsui, E., Shekhar, S. 2007. Trust as an antecedent to knowledge sharing in virtual communities of practice. Knowledge Management Research \& Practice, 5(3), 199-212.

Vandenberghe, C., Bentein, K., Stinglhamber, F. 2004. Affective commitment to the organization, supervisor, and work group: antecedents and outcomes. Journal of Vocational Behavior, 64, 47-71.

Wahyudi, S., Udin, U., Yuniawan, A., Rahardja, E. 2019. Person-Organization Fit, Knowledge Sharing Behaviour, and Innovative Work Behaviour: A Selfdetermination Perspective. International Journal of Innovation, Creativity and Change, 4(4), 145-161.

Wang, S., Noe, R.A. 2010. Knowledge sharing: A review and directions for future research. Human Resource Management Review, 20(2), 115-131. 